\title{
MAKNA JASA PINJAMAN DALAM UNIT USAHA SIMPAN PINJAM
}

\author{
Alif Ilham Akbar Fatriansyah \\ Iwan Triyuwono \\ Roekhudin \\ Faculty Economics and bussiness University of Brawijaya, City of Malang \\ alifatriansyah@ymail.com \\ Roekhudin@gmail.com
}

\begin{abstract}
This study aims at understanding the meaning of the loan in the loan business services based on the members' perceptions of Eko Kapti cooperative. This study uses Transcendental Phenomenology approach by Edmund Husserl. The results of this study show that the "the loan services are the results of inconsistencies in the use of a principle", whether using syariah or conventional principles, so that the existing loan business services are considered as part of syariah containing usury.
\end{abstract}

Keywords: Understanding the meaning of the loan services, Cooperatives, Inconsistency, Syariah or Conventional

\section{PENDAHULUAN}

Berdasarkan sejarah di Indonesia, koperasi lahir, hidup dan berkembang berawal dari proses simpan pinjam sebagai unit usaha dalam koperasi, simpan pinjam merupakan salah satu sumber pendapatan untuk koperasi dengan cara menghimpun dana simpanan pokok dan wajib para anggota kemudian disalurkan kembali terhadap anggota yang membutuhkan dalam bentuk pinjaman uang, namun dalam setiap pengembalian dana pinjaman tersebut, selain pokok pinjaman anggota juga dikenakan biaya tambahan atas "jasa" yang biasa disebut jasa pinjaman. Disadari atau tidak "jasa" yang digunakan di koperasi sama dengan "bunga" ada di bank, jika di koperasi "jasa" tersebut dibagikan kembali ke anggota dalam bentuk SHU (sisa hasil usaha), sedangkan "bunga" di bank tidak dibagikan.

Di sistem ekonomi Islam fenomena jasa pinjaman dalam unit usaha simpan pinjam banyak diperdebatkan keabsahannya termasuk dalam koperasi, penelitian ini bukan untuk mencari kebenaran akan tetapi mencari makna jasa pinjaman dari informan terpilih, walaupun begitu dalam dunia pengetahuan adanya perbedaan persepsi tentang suatu persoalan merupakan keniscayaan selama didasari oleh dalil yang kuat (Susamto, 2013). Perdebatan itu hal yang lumrah asal tidak bertentangan dengan fikih, ditegaskan oleh Arini (2013) bahwa kaidah fikih pada dasarnya segala bentuk muamalat boleh dilakukan kecuali ada dalil yang mengharamkan. Banyak aspek dan sudut pandang yang berbeda menyebabkan menjadi perdebatan, selain itu tingkat kesadaran atas pengetahuan juga mempengaruhi.

Tujuan utama seharusnya koperasi dan ekonomi Islam untuk mewujudkan kemakmuran dan kesejahteraan, keyakinan ini disadari oleh Syaifullah (2016) bahwa kemakmuran atau kesejahteraan hidup di bumi hanya bisa diwujudkan dengan bekerja yang menghasilkan nilai ekonomi dan sosial, sebagai kontribusi pada proses pembangunan yang bertujuan menciptakan 
kemakmuran. Untuk menciptakan kemakmuran harus menghindari ketidakadilan yang sesuai dengan syariat Islam (Tarmizi, 2016) salah satunya opsinya dengan bagi hasil, hal ini dibenarkan oleh Sugianto (2014) bahwa rate of profit dengan sistem bagi hasil yang ada di koperasi dan ekonomi Islam dapat menciptakan keadilan distributif dalam pendapatan dan kekayaan masyarakat.

Hal lain yang jadi pertimbangan penelitian terkait dengan adanya beberapa pernyataan seperti Saktijaningdijah (2016) bahwa masyarakat bisa mendapatkan pinjaman dari koperasi dengan syaratsyarat yang mudah dan ketentuan "bunga" yang kurang lebih sama dengan "bunga bank", adanya anggapan ini menunjukkan "jasa" di koperasi sama dengan "jasa" di bank, seperti juga dalam penelitian Tsabita (2014) sistem ini (jasa) bisa termasuk dalam penyimpangan karena memastikan sesuatu yang belum pasti, dibingkai dalam ekspektasi cash flow yang dibuat oleh pemilik dana, peneliti lain menyebutkan konsep "bunga" dan "riba" dalam persepsi Islam terdapat persamaan, bahwa "bunga" merupakan tambahan yang dikenakan dalam transaksi pinjaman uang (al-qardh) yang diperhitungkan dari pokok pinjaman tanpa memperhitungkan pemanfaatan/hasil pokok tersebut berdasarkan tempo waktu yang diperhitungkan secara pasti di muka dan berdasarkan persentase (Rahim, 2015).

Hal lain coba diungkapkan oleh Syarif (2011) dalam tulisannya mengatakan menurut al-Qurthubi bahwa yang dikatakan riba pada Al-Quran surah Al-Rum ayat 39 adalah riba nassi'ah, sebagaimana dipraktikkan oleh keluarga tsaqif yang berarti sebagai riba Al-Quran, yang secara jelas dilarang dalam Al-Quran surah itu termasuk ayat makiyyah di mana yang lebih dominan berbicara masalah akidah (theologi), pendapat ini dibenarkan oleh Abd al-Azhim Jalal Abu Zayd (Syarif, 2011) bahwa riba dalam surah ini bukanlah yang diharamkan, penafsiran ini dikuatkan oleh kesimpulan Manunggal (2011) riba dapat terjadi juga dalam perdagangan, tidak hanya pinjaman. Dari ungkapan diatas ditemukan bahwa sebenarnya riba ada yang dilarang dan juga tidak, sehingga penjelasan diatas menunjukkan tidak boleh menggeneralisasi tentang riba.

Salah satu lembaga keuangan bukan bank yang menjalankan unit usaha simpan pinjam adalah Koperasi Eko Kapti di Kabupaten Malang. Koperasi ini didirikan pada tanggal 12 September 1969 dengan nama awal Primer Koperasi Pegawai Eko Kapti Kantor Departemen Agama Kabupaten Malang/Kotamadya Malang. Badan hukum nomor: 168/BH/II/17 - 69 Tanggal 12 September 1969, berkedudukan di Jalan Aries Munandar 35 Malang. Koperasi ini berada di bawah naungan Kementerian Agama dengan ruang lingkup kerja Kabupaten Malang dan Kota Batu.

Dilihat dari realitasnya jasa pinjaman dalam unit usaha simpan pinjam secara sosial atau kontekstual lumrah terjadi dalam masyarakat dan koperasi khususnya dalam koperasi Eko Kapti. Menurut Zulfa (2012) melihat realitas seperti itu tentunya kita bertanya bolehkah dengan sebuah prinsip tertentu suatu teks bisa dipahami tidak secara tekstual harfiah. Dilihat dari tujuan dan manfaatnya banyak berdampak terhadap anggota seperti adanya keadilan yang diterima, mengurangi beban hidup, ditegaskan dalam pendapat Tsabita (2014) keadilan menurut Islam sebenarnya bersifat fundamental berpijak pada nilai-nilai etika syariah dan moral, selain itu melihat ukuran dengan perbuatan dzolim dan ketidakadilan dalam transaksi (Manunggal, 2011). Realitas lain berusaha diungkapkan oleh Saktijaningdijah (2016) terhadap koperasi yang ternyata hanya mengejar keuntungan semata sehingga dalam praktiknya seringkali menyimpang dari ketentuan yang berlaku.

Penelitian ini bertujuan untuk memahami kesadaran yang dimiliki informan dalam suatu fenomena, sehingga akan menghasilkan jawaban dalam mencari 
makna berdasarkan kesadaran yang dimiliki informan terhadap jasa pinjaman, oleh karena itu hasil peneliti yang didapat merupakan persepsi dari masing-masing informan atas kejadian yang sesungguhnya, terhadap realitas sebenarnya yang telah lama terjadi namun jarang diungkapkan informan. Berdasarkan latar belakang dan penjelasan yang mendukung, pertanyaan penelitian ini adalaha bagaimana anggota memaknai jasa pinjaman dalam unit usaha simpan pinjam dalam koperasi Eko Kapti?. Metodologi yang digunakan untuk mencari makna dari penggalian informasi informan yaitu fenomenologi. Mengapa fenomenologi? karena metodologi ini dirasakan tepat untuk menggali nilai-nilai dalam pengalaman dan kehidupan tingkat kesadaran para informan, sehingga akan menemukan makna dan hakikat dari pengalaman.

\section{METODE PENELITIAN}

Pada penelitian ini paradigma yang digunakan interpretif. Paradigma interpretif menggambarkan dunia sosial dari sudut pandang informan yang terlibat didalamnya dalam menyikapi suatu fenomena. Dunia sosial yang ada ketika seseorang berada di lingkungan tempatnya melakukan aktifitas sehari-hari, sehingga informan menyadari hal tersebut. Penelitian ini berusaha mengungkapkan fenomena sosial yang terjadi dalam hubungan saling mempengaruhi secara koheren antara "aku" sebagai pusat informasi dan pengalaman. Keterlibatan informan sebagai upaya dasar untuk bisa menjawab pertanyaan penelitian. Paradigma interpretif yang dalam banyak hal disebut sebagai paradigma kontruktif, menekankan bahwa penelitian pada dasarnya dilakukan untuk memahami realitas dunia apa adanya, suatu pemahaman atas sifat fundamental dunia sosial pada tingkatan pengalaman subyektif.

Penelitian ini menggunakan paradigma interpretif dengan pendekatan fenomenologi. Fenomenologi merupakan sebuah pendekatan filosofis sosial untuk menyelidiki kesadaran manusia yang memiliki pengalaman panjang dengan melihat interaksinya. Fenomenologi yang digunakan dalam penelitian ini mendapatkan kontribusi dari Edmund Husserl yang biasa disebut dengan fenomenologi transcendental dengan menyatakan bahwa ilmu sangat ditentukan oleh karakter intensionalitas. Penelitian dengan karakter intensionalitas fokus pada sesuatu yang dialami dalam kesadaran individu, sedangkan intensionalitas menggambarkan hubungan antara proses yang terjadi dalam kesadaran obyek yang menjadi perhatian pada proses.

Peneliti ingin mengetahui tingkat kesadaran informan terhadap sesuatu hal yang ada disekitarnya. Kesadaran akan menjadi penting jika ada keselarasan dan kepemahaman mengenai fenomena. Fenomena ini yang coba peneliti ingin mengetahui lebih mendalam, dengan cara mendeskripsikan simbol-simbol yang informan berikan, simbol ini bisa didapat melalui ucapan, gerakan atau gestur tubuh yang lainnya. Fokus fenomenologi terhadap pengalaman partisipan, yang menjelaskan secara struktur dari kesadaran yang realitas dan subyektif alamiah, oleh karena itu pengalaman subyektif setiap informan pasti akan berbeda sehingga kita tidak bisa menyalahkan ataupun membenarkan.

\section{HASIL DAN PEMBAHASAN \\ HASIL INFORMAN 1}

Pemahaman atas subyek sebagai fenomena bisa dimaknai sesuai dengan kesadaran masing-masing disertai pengalaman yang akan mampu menceritakannya secara detail, tanpa pengalaman tidak bisa mengetahui tingkat kesadaran seseorang. Butuh kesadaran dan ketelitian dalam mencari makna tersembunyi dari suatu pengalaman yang diceritakan, sehingga keberadaan informan sebagai obyek utama dalam deskripsi pengalaman menjadi sangat vital. Ketergantungan akan kesadaran seseorang sebagai poros menjadi hal yang utama dalam membentuk 
fenomena dari transcendental Husserl.

Peneliti awali observasi dengan informan 1, beliau merupakan salah satu anggota koperasi yang telah lama bergabung dan sekarang memiliki jabatan sebagai ketua koperasi Eko Kapti. Pertama kali bertemu, informan 1 lebih banyak berbincang mengenai awal karir hingga menjadi ketua koperasi, beliau merupakan sosok yang ramah, tegas, berpandangan luas, baik, dan bisa menerima pendapat orang lain (begitu beliau menceritakan kisahnya), selain itu dalam memberikan informasi beliau sangat fokus. Beliau dipilih (berdasarkan keputusan rapat) menjadi informan selain karena pimpinan koperasi, beliau mengetahui perkembangan jasa pinjaman yang menjadi fenomena penelitian.

Berdasarkan cerita beliau, sebenarnya ada keinginan untuk mengundurkan diri, karena beranggapan sudah waktunya ada pergantian dengan memberikan kesempatan pada yang lain untuk memimpin. Usaha beliau (sebenarnya) sudah berulang kali disampaikan pada saat rapat anggota, tetapi teman-teman yang lain (anggota koperasi yang diwakili oleh dewan anggota) masih berharap beliau memimpin koperasi. Informan 1 lebih banyak berbicara berdasarkan pengalaman berada di koperasi dan apa yang dipelajari, sehingga hasil yang disampaikan murni tingkat kesadaran beliau. Dalam observasi terhadap informan
1, peneliti beranggapan bahwa informasi yang diberikan merupakan kesadaran posisi beliau sebagai anggota bukan ketua koperasi. Temuan dalam penelitian akan diuraikan dibawah ini dimana merupakan hasil dari analasis yang dilakukan oleh peneliti sehingga menemukan makna jasa pinjaman.

Simpulan dari informan 1 yaitu Memaknai sebagai "jasa pinjaman dalam unit usaha simpan pinjam merupakan bagian dari syariah", dimana terdapat (akad, keterlibatan, dan keikhlasan) dari para anggota yang diwakilkan dewan anggota, jika terdapat hal yang tidak sesuai maka anggota bisa sampaikan melalui dewan anggota melalui "rapat anggota", walaupun begitu yang benar-benar murni syariah hanya untuk usaha, sehingga tidak mungkin bahwa "bangun rumah, bayar sekolah, dan bayar kuliah" masuk kategori usaha, karena belum ditemukan cara perhitungan bagi hasilnya, sedangkan perbandingan antara yang meminjam jasa untuk usaha sangat sedikit. Jika menerapkan prinsip syariah murni sebagai "usaha" anggota harus bisa "jujur, transparan dan bisa dipercaya".

Kesadaran beliau sebagai "aku" yang pernah mengalami, mempelajari dan menyadari tentang jasa pinjaman tertuang jelas. Simpulan merupakan refleksitas atas pencarian makna yang didapat dari informan, menceritakan secara deskripsi

\section{Gambar 1 Tingkat Kesadaran Informan 1}

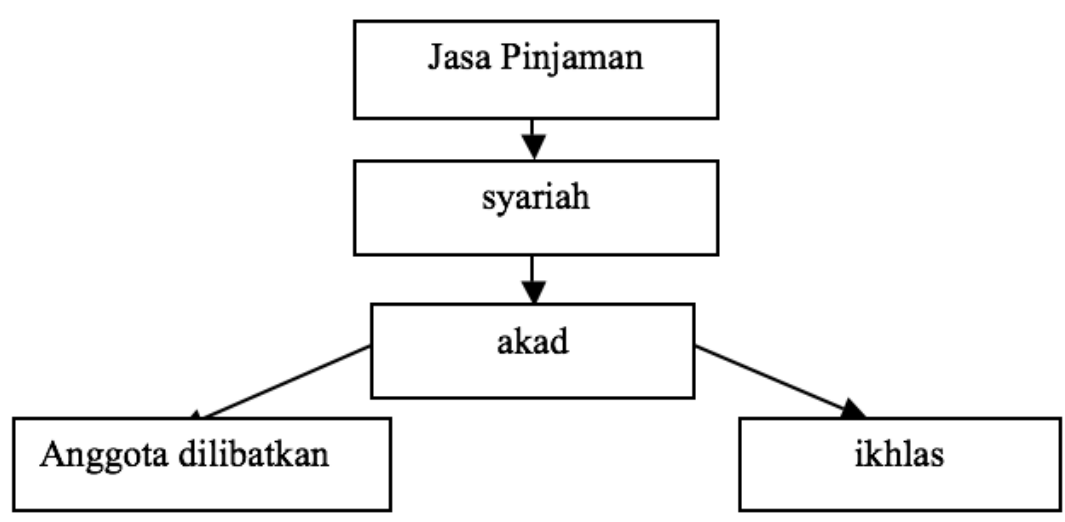


disertai pengalamannya sebagai anggota yang mempelajari syariah dan konvensional menunjukkan refleksi atas apa yang terjadi dalam fenomena selama ini. Berdasarkan simpulan tersebut peneliti memberikan sebuah gambaran terhadap kesadaran informan 1 dalam melihat fenomena jasa pinjaman bisa dilihat pada gambar 1 .

\section{Hasil Informan 2}

Setiap lembaga keuangan memiliki orientasi berbeda dengan yang lain, ada yang berorientasi dengan keuntungan atau ada juga yang berorientasi terhadap distribusi kekayaan yang merata seperti koperasi. Salah satu lembaga keuangan yang banyak di Indonesia yaitu koperasi, walaupun sama-sama mencari keuntungan namun tidak menjadi hal prioritas. Koperasi salah satu tujuannya untuk menciptakan kebermanfaatan terhadap anggota, oleh karena itu tidak heran jika kemunculannya dapat diterima disemua kalangan.

Dalam situs penelitian ini, informan 2 berbeda dengan informan 1 . Jika informan 1 merupakan pegawai negeri sipil di Kementerian Agama Kabupaten Malang yang secara otomatis menjadi anggota koperasi Eko Kapti ketika bertugas disana, namun informan 2 adalah pegawai yang bekerja untuk koperasi tetapi ternyata juga dimasukkan dalam keanggotaan hanya bersifat ketika masih menjadi pegawai dimana biasa disebut dengan "anggota luar biasa".

Hal yang ingin diungkapkan, apakah pendapat informan 2 terpilih tentang jasa pinjaman, oleh karena itu peneliti ingin secara langsung mengetahui dan mencari makna. Pegawai toko koperasi merupakan "anggota luar biasa" yang dimiliki sebagai pekerja dalam unit usaha koperasi, karena bersifat luar biasa ada beberapa hal yang tidak didapat pegawai, seperti tidak ada hak suara dalam rapat anggota, selain itu tentang lama dan jumlah pinjaman, walaupun begitu "anggota luar biasa" dalam proses proses sama dengan "anggota pegawai".
Dalam bagian ini peneliti akan menganalisis kesadaran sehingga memunculkan makna yang dimiliki oleh informan 2, dimana penempatan sekarang beliau berada di kasir toko, beliau bergabung dari tahun 1999. Informan 2 merupakan salah satu pegawai toko perempuan senior yang dimiliki oleh koperasi. Alasan terpilih beliau adanya rekomendasi dari para pengurus, selain itu sebagai salah satu perwakilan dari para pegawai toko. Tentu informasi yang akan diberikan beliau berbeda dengan para pegawai lain ataupun anggota koperasi, sehingga hasil dari tulisan di bagian ini berdasarkan pengalaman informan 2 menyadari fenomena "jasa pinjaman".

Dalam menyampaikan informasinya, beliau tidak lupa memberikan contoh berdasarkan fakta yang telah terjadi disertai dengan pengalaman dari anggota lain yang "cerita" terhadap beliau. Berdasarkan observasi terhadap informan 2, beliau merupakan sosok perempuan yang ramah, tutur kata baik, pengetahuan luas dan memiliki informasi yang banyak mendapat pengaruh dari anggota lain, sehingga berpengaruh terhadap sudut pandang "jasa pinjaman" dalam unit usaha simpan pinjam yang selama ini terjadi di Koperasi Eko Kapti.

Simpulan dari informan 2, memaknai " jasa pinjaman merupakan bagian dari bunga", yang tidak sesuai dengan prinsip syariah, tetapi dilarangnya "jasa" tersebut hanya dilakukan untuk "bayar sekolah dan bayar kuliah", kalau "bangun rumah" diperbolehkan menggunakan "jasa pinjaman". Alasan tidak diperbolehkan untuk "pembayaran sekolah dan kuliah" karena jika dihitung menggunakan bagi hasil tidak bisa, sedangkan penggunaan jasa pinjaman untuk "pembiayaan rumah" lebih mudah dihitung bagi hasilnya.

Perbedaan antara jasa dalam koperasi dengan bank, jika jasa koperasi akan dibagikan ke anggota kembali melalui SHU (sisa hasil usaha), namun jika jasa dari bank tidak dibagikan, walaupun memaknai sama 
dengan "bunga" di bank, informan 2 mengakui keberadaan "jasa" yang "menyebabkan" koperasi Eko Kapti tidak syariah secara "utuh", namun keberadaan beliau sebagai "anggota luar biasa" memiliki keterbatasan dalam menyampaikan pendapat sehingga selama ini beliau menjadi anggota mengikuti segala keputusan rapat anggota.
Kepanjen, Kabupaten Malang, alasan terpilih beliau dikarenakan ada salah satu pengurus yang merekomendasikannya. Informan 3 bergabung lebih kurang 5 tahun dalam koperasi Eko Kapti. Dalam mencari makna atas kesadaran beliau terhadap jasa pinjaman, informan 3 memberikan penjelasan atas keilmuan

\section{Gambar 2 Tingkat Kesadaran Informan 2}

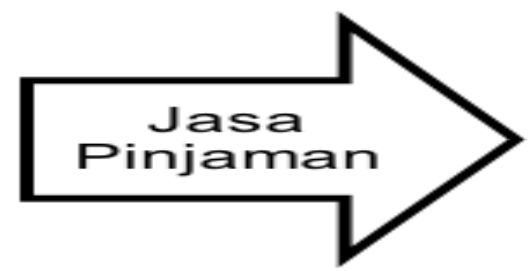

Hasil Informan 3

Kesadaran seseorang bertambah ketika pengalaman atas pengetahuan meningkat, oleh karena itu setiap kesadaran orang pasti berbeda, walaupun pengalaman atas pengetahuan sama tapi kemampuan untuk memahami dipastikan berbeda. Realistis dan idealis setiap orang mempunyai tingkatan yang berbeda, oleh sebab itu kita tidak boleh menggeneralisasikan semua hal harus selalu sama. Setiap sudut pandang dipengaruhi oleh kemampuan untuk bisa menganalisis apa yang terjadi.

Fenomena yang berada di sekitar kita, sering terjadi setiap waktu tapi apakah kita menyadarinya atau tidak, apakah ini sesuai atau tidak, tapi banyak juga yang tidak peduli akan fenomena tersebut. Seharusnya ketika seseorang menemukan suatu ketidaksesuain dengan apa yang dipahami, alangkah baiknya untuk memberikan masukan, saran atau kritik. Begitu juga dalam penelitian ini, seorang informan diminta untuk bisa menceritakan suatu fenomena secara detail lalu mengungkapkannya, sehingga hasil dari ungkapan atas fenomena setiap informan dipastikan berbeda.

Informan 3 merupakan seorang pria anggota koperasi Eko Kapti yang bertugas di KUA (Kantor Urusan Agama) daerah

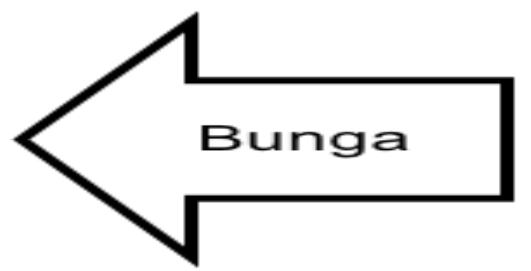

yang pernah didapat selama menempuh pendidikan, latar belakang pendidikan tersebut yang menentukan pola pikir dalam mengungkapkan fenomena jasa pinjaman. Informan 3 merupakan sosok yang tegas, berpandangan luas terhadap keilmuan dan mampu mendeskripsikan secara jelas.

Pada saat observasi dilakukan terhadap informan 3, ditemukan jawaban baru yang berbeda dari informan 1 dan informan 2 , dengan mampu menggambarkan apa yang sebenarnya terjadi dalam Jasa Pinjaman khususnya di Koperasi Eko Kapti. Hasil temuan akan diuraikan dalam simpulan yang tertera. Simpulan tersebut berisikan pemahaman informan 3 dalam menganalisis kesadaran pengalamannya.

Simpulan yang didapat dari informan 3, Memaknai "Jasa pinjaman sebagai "distorsi" antara praktik dan teori", karena jika menggunakan syariah tidak ada "jasa" yang ada jual-beli (murobahah), namun yang terjadi selama ini di Koperasi Eko Kapti terdapat "ketidakkonsistenan antara jasa dan jual-beli (murobahah)" dalam penerapan selama ini, karena jika dikatakan jasa kurang tepat, tapi jika dikatakan jualbeli juga kurang tepat, walaupun begitu beliau sendiri tidak mengetahui secara langsung apakah koperasi Eko Kapti syariah 


\section{Gambar 3 Tingkat Kesadaran informan 3}

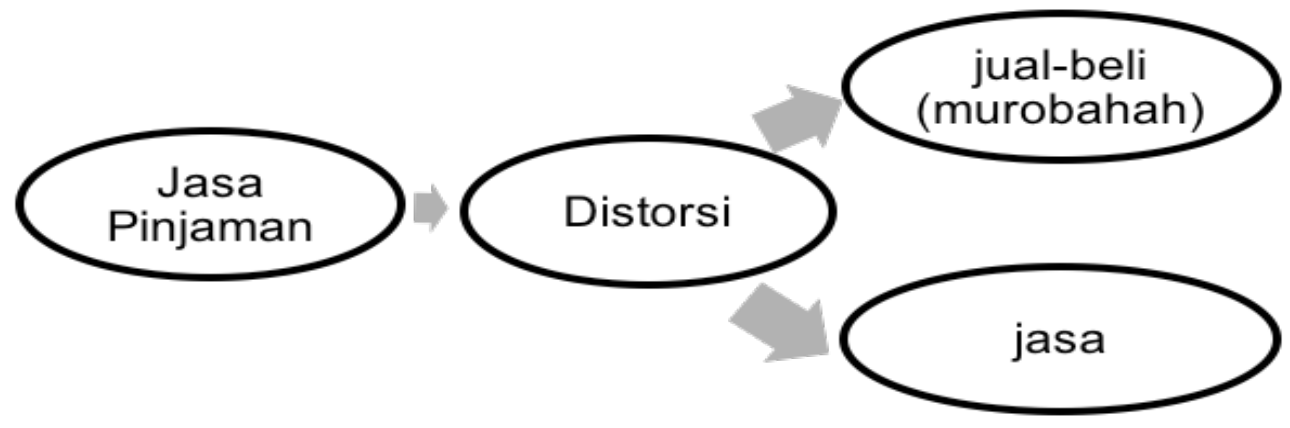

atau konvensional, tapi yang beliau lakukan selama ini menjadi anggota "guyub" atau sepakat.

\section{SIMPULAN}

Makna jasa pinjaman dalam unit usaha simpan pinjam dapat dilihat ketika menganalisis setiap informasi yang diberikan, tidak terlepas dari kesadaran yang melekat pada diri sendiri, karena kesadaran merupakan gambaran terhadap pola pikiran dan hati nurani untuk memahami dan mendalami setiap fenomena disekitarnya. Tidak bisa disampingkan begitu saja bahwa sebenarnya realitas yang ada utuh dan berbentuk hierarki, oleh karena itu perlu ada pemahaman yang sejalan dengan konsep awal agar tidak terjadi persimpangan. Hierarki akan kehadiran jasa pinjaman menggambarkan tingkat kesadaran, peran sebagai anggota, dan sifat menentukan dalam rapat.

Sistem syariah murni ternyata hanya bisa digunakan untuk usaha, oleh sebab itu yang hanya diperbolehkan jual-beli (murobahah), dimana kebutuhan anggota dibelikan terlebih dahulu oleh koperasi setelah itu dijual kembali keanggota dengan membuat selisih harga sebagai pendapatan untuk koperasi, dengan pembayaran disesuaikan kesepakatan, kemampuan bersama dalam akad yang disepakati. Hal ini yang seharusnya dipraktikan oleh lembaga keuangan jika menggunakan prinsip syariah untuk menghindari riba atau bunga bank, seperti dalam surat berikut: "Allah telah menghalalkan jual beli dan mengharamkan riba”. (Al-Baqarah: 275).

Ketika Allah menghalalkan jual-beli ini sependapat dengan jalan pemahaman para informan, ditambah dengan ada kesadaran informan lain bahwa selama ini jasa pinjaman didalam simpan pinjam merupakan "riba" yang menurut sistem syariah itu dilarang. Hal itu dapat dilihat dari surat berikut: "Allah memusnakan riba dan menyuburkan sedekah". (Al-Baqarah: 276)

Yang terjadi dalam koperasi Eko Kapti sebenarnya adanya "ketidakkonsistenan" dalam penerapan prinsip yang digunakan, penetapan prinsip dalam AD/ART (Anggaran Dasar/Aturan Rumah Tangga) seharusnya diterapkan secara benar dan seksama hingga unit usahanya. Untuk tidak menimbulkan perbedaan persepsi antar anggota, selain itu untuk bisa memperlakukan secara tepat unit usaha yang ada.

Kendala yang terjadi bahwa koperasi Eko Kapti merupakan bagian dari Kementerian Agama yang bertugas untuk menyelenggarakan fungsi pemerintahan dalam pembimbingan dan pengelolaan fungsi administratif dari kegiatan keagamaan di Indonesia, sehingga tidak leluasa untuk menerapkan prinsip syariah atau prinsip konvensional, selain itu juga prinsip yang digunakan dalam koperasi harus bertujuan memajukan kesejahteraan anggota pada khususnya dan masyarakat pada umumnya, serta ikut membangun tatanan perekonomian nasional dalam rangka mewujudkan masyarakat yang maju, adil, 


\section{Gambar 4.1 Sintesa Jasa Pinjaman Informan}

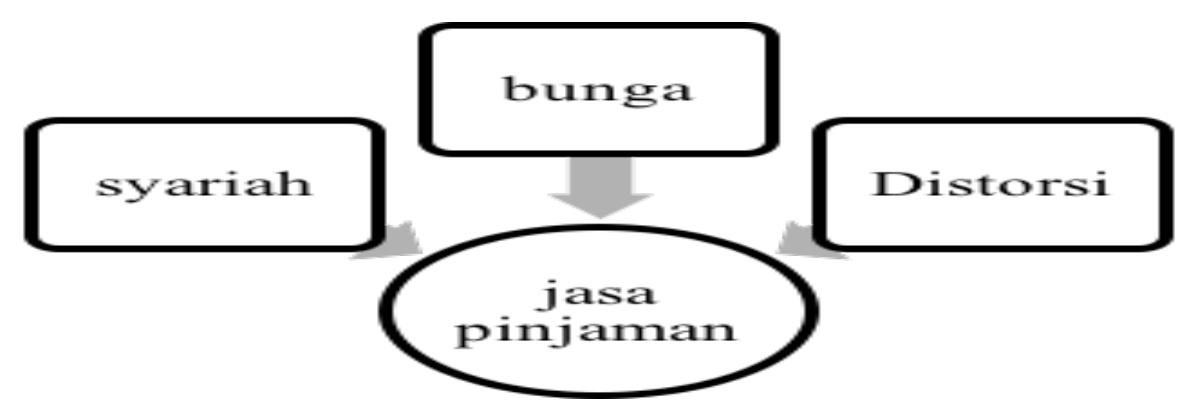

dan makmur berlandaskan Pancasila dan Undang-Undang Dasar 1945, bunyi Pasal 3 Undang-Undang Nomor 25 Tahun 1992 Tentang Perkoperasian.

Sintesa yang didapat peneliti setelah menelaah secara keseluruhan kesadaran para informan, sehingga peneliti menyimpulkan "Jasa pinjaman merupakan penerapan ketidakkonsistenan dalam menggunakan suatu prinsip, yaitu antara prinsip syariah atau prinsip konvensional, sehingga jasa pinjaman yang selama ini terjadi dianggap sebagai bagian dari syariah yang mengandung riba.

Adapun saran yang dapat diajukan peneliti untuk penelitian yang akan datang adalah sebagai berikut. 1). Perlu adanya kejelasan status yang dimiliki oleh koperasi apakah berbentuksyariah atau konvensional, karena akan mempengaruhi perlakuan terhadap unit usahanya. 2). Perlu adanya penjelasan secara mendalam tentang jasa pinjaman antara koperasi syariah dan koperasi konvensional, bisa dilakukan dengan pelatihan, mengundang pemateri, atau study banding dengan koperasi lain, hal ini dimaksudkan agar memberikan pengetahuan terhadap para anggota untuk tidak menimbulkan perbedaan pandangan. 3). Mengembangkan tentang kebijakan jasa pinjaman yang selama ini sudah dijalankan sebagai upaya untuk menyempurnakan unit usahanya. 4). Melakukan kajian internal untuk mengetahui pendapat tentang jasa pinjaman dari para anggota yang memiliki latar belakang berbeda. 5). Mengkaji secara mendalam tentang unit usaha simpan pinjam antara koperasi syariah dan koperasi konvensional.

\section{DAFTAR PUSTAKA}

Al-Quran digital versi Android. (2014). Tangerang Selatan. Andi Unpam

Arini, R. D. (2013). Analisis Kesyariahan Transaksi Logam Mulia (Emas) di Perbankan Syariah (Studi Pada Bank X Syariah). Magister IImu Ekonomi. Universitas Brawijaya Malang.

Asdar. (2014). Praktik Akuntansi Dalam Pengelolaan Masjid. Thesis tidak dipublikasikan. Magister Ilmu Akuntansi. Fakultas Ekonomi dan Bisnis. Universitas Brawijaya Malang.

Antonio, M.S. (2017). Bank Syariah Dari Teori Ke Praktek. Gema Insani. Cetakan ke 27. Jakarta. Indonesia

Buchori, N.S. (2013). Koperasi Syariah Dari Teori Ke Praktek. Pustaka Aufa Media. http.// kisbazarbukuonline.blogdetik.com. Indonesia

Darmayasa, I.N dan Aneswari, Y.R. (2015). Paradigma Interpretif Pada Penelitian Akuntansi Indonesia. Jurnal Akuntansi Multiparadigma. Vol. 6, No. 3 Hal.350.

Djamhuri, A. (2011). Ilmu Pengetahuan Sosial Dan Berbagai Paradigma Dalam Kajian Akuntansi. 
Jurnal Akuntansi Multiparadigma. Vol. 2, No 1 hlm 147-185.

Farida, W. (2017). Memahami Kesadaran Peran Akuntan Pendidik Dalam Pembelajaran Akuntansi. Thesis tidak dipublikasikan. Program Magister Akuntansi. Pascasarjana Fakultas Ekonomi dan Bisnis Universitas Brawijaya Malang.

Hadi, S. (2017). Pragmatisme Akuntansi, Tren atau Jebakan?: Studi Fenomenologi Kesadaran User Dalam Praktik Adopsi Cloud Accounting Pelaporan Keuangan Pemeritah Pusat di Indonesia. Thesis tidak dipublikasikan. Program Magister Akuntansi. Pascasarjana Fakultas Ekonomi dan Bisnis Universitas Brawijaya Malang.

Hasbiansyah. (2008). Pendekatan Fenomenologi: Pengantar Praktik Penelitian dalam IImu Sosial dan Komunikasi. Mediator. Vol. 9, No. 1 Hal.163-164.

Hasmayati. (2016). Analisis Penilaian Kesehatan Koperasi Jasa Keuangan Syariah Berbasis Masjid (Studi Kasus Koperasi Jasa Keuangan Syariah Baitul Mal Tamwil AT-TaqwaMasjid AT-Taqwa Kemanggisan Jakarta). JRMB, Jurnal Riset Manajemen dan Bisnis. Vol. 1, Nom. 2 163-170.

Husserl, E. (1987). The Crisis of European Sciences and transcendental Phenomenology: An Introduction to Phenomenological Philosophy. Trans. David Carr. Evanston. Nortwestern University Press.

Husserl, E. (1982). Cartesin Meditations: An Introduction to Phenomenology. Trans. Dorion Cairns. The Hague Boston. London. Martinus Nijhoff Publisher

Kamayanti, A. (2016). Metodologi Penelitian Kualitatif Akuntansi. Pengantar Religiositas Keilmuan. Cetakan Pertama. Yayasan Rumah Peneleh, Jakarta Selatan.

Keputusan Menteri Koperasi Nomor 91/Kep/M.KUKM/IX/2004. Tentang Petunjuk Pelaksanaan Kegiataan Usaha Koperasi Jasa Keuangan Syariah.

Kuswarno, E. (2009). Fenomenologi Konsepsi, Pedoman, dan Contoh Penelitian. Bandung. Widya Padjajaran.

Manunggal, S.A.M. (2011). Etika Islam Dalam Manajemen Keuangan. Jurnal Hukum Islam (JHI). Vol. 9, No, 2, 170-188.

Mulawarman, A. D. (2005). Menuju Rekontruksi Teknologi Integralistik Akuntansi Syari"ah:Shari'ate value Addes Statement. Thesis tidak dipublikasikan. Program Studi Akuntansi Minat Akuntansi Syariah. Universitas Brawijaya. Malang.

Muliya, L.I, dan Imaniyati, N.S. (2008). Perusahaan Modal Ventura Dalam Perspektif Hukum Bisnis Dan Hukum Islam. Penerbit Fakultas Hukum Universitas Islam Bandung. Bandung.

Muheramtohadi, S. (2017). Peran Lembaga Keuangan Syariah Dalam Pemberdayaan UMKM di Indonesia. Muqtasid, Jurnal Ekonomi dan Perbankan Syariah. Vol 8(1), No. 94-112.

Moustakas, C. (1994). Phenomenological Research Method. SAGE Research Methods. Online ISBN: 9781412995658 DOI: 10.4135/9781412995658. Pages: 1-25

Nur. M. (2015). Pergulatan Syariahisasi Kerangka Konseptual Akuntansi Di Indonesia. Disertasi. Program Doktor IImu Akuntansi. Universitas Brawijaya. Malang

Noviransi, E. (2015). Studi Fenomenologi Atas Dilema Etis Auditor Internal Pemerintah. Thesis tidak dipublikasikan. Magister Akuntansi. Fakultas Ekonomi dan Bisnis Universitas Brawijaya Malang.

Pasaribu, C. Suhrawadi K.L. (1994). Hukum Perjanjian Dalam Islam. Sinar Grafika. Cetakan ke 1. Jakarta

Rachmawati. (2017). Studi Fenomenologi Atas Implementasi Akuntansi Berbasis Akrual Pada Badan Layanan Umum Daesrah RSUD Dr. Saiful Anwar Malang. Thesis tidak dipublikasikan. Program Magister Akuntansi. Pascasarjana Fakultas Ekonomi dan Bisnis Universitas Brawijaya Malang.

Rahmat, P.S. (2009). Penelitian Kualitatif. Equilibrium. Vol. 5, No. 9 p 1 
Rahim, A. (2015). Konsep Bunga dan Prinsip Ekonomi Islam Dalam Perbankan Syariah. Human Falah. Vol. 2, No. 2 p.1

Riharjo, I.B. (2011). Memahami Paradigma Penelitian Non-Positivisme Dan Implikasinya Dalam Penelitian Akuntansi. Jurnal Akuntansi, Manajemen Bisnis Dan Sektor Publik (JAMBSP). Vol. 8, No. 1 128-146.

Susamto, B. (2013). Penerapan Prinsip Syariah Dalam Lembaga Perasuransian Di Indonesia. de Jure, Jurnal Syariah dan Hukum. Vol. 5, No. 1 HIm 97-106.

Susamto, B. (2013). Koperasi Syariah dan Pengaturannya di Indonesia. UIN Maliki Press. Cetakan ke 2. Indonesia.

Saktijaningdijah. (2016). Menelusuri Makna Denda Angsuran Pinjaman Di Koperasi. Thesis tidak dipublikasikan. Program Magister Akuntansi. Pascasarjana Fakultas Ekonomi dan Bisnis Universitas Brawijaya Malang.

Santoso, H. (2016). Pelaksanaan Keadilan Upah Bagi "Pekerjaan Malam Wanita". Thesis tidak dipublikasikan. Program Magister Akuntansi. Pascasarjana Fakultas Ekonomi dan Bisnis Universitas Brawijaya Malang.

Sekaran, U. (2009). Research Methods For Business. Salemba Empat. Edisi 4. Jakarta.

Soedarso, E.H. (2011). Membangun Konsep Penilaian Kinerja Koperai Syari'ah Berdasarkan Perspektif Shari'ate Enterprise Theory. Thesis tidak dipublikasikan. Program Magister Akuntansi. Pascasarjana Universitas Brawijaya Malang.

Syaifullah, E. (2016). Pembangun Dalam Islam. I-Finance. Vol. 2, No. 2, Hal 95-98.

Syahrina, D. (2016). Mengungkapkan Fenomena Fraud (Studi Etnografi Pengelolaan Keuangan Negara). Thesis tidak dipublikasikan. Program Magister Akuntansi. Pascasarjana Fakultas Ekonomi dan Bisnis Universitas Brawijaya Malang.

Syarif, M. I. (2011). Konsep Riba Dalam Al-Quran Dan Litelatur Fikih. Al-lqtishad. Vol. III, No.2.

Susila, A.A. (2014). Strategi Kesuksesan Koperasi BMT Maslahah Dalam Pengembangan Usaha dan Pemberdayaan Ekonomi Umat. Tesis. Gelar Magister Dalam IImu Ekonomi Islam. Program Studi Hukum Islam Konsentrasi Keuangan dan Perbankan Syariah. UIN Sunan Kalijaga. Pascasarjana Yogjakarta.

Sugianto. (2014). Pengakuan Pendapatan Atas Pembiayaan ljarah. Thesis tidak dipublikasikan. Program Magister Akuntansi. Pascasarjana Fakultas Ekonomi dan Bisnis Universitas Brawijaya Malang.

Tarmizi, E. (2016). Harta Haram Muamalat Kontemporer. Berkat Mulia Insani Publishing. Cetakan ke-12 Bogor.

Triyuwono, I. (2013). So, What Is Sharia Accounting?. Jurnal Ekonomi, Manajemen dan Akuntansi Islam IMANENSI. Vol. 1, No. 1.

Triyuwono, I. (2013). Makrifat Metode Penelitian Kualitatif dan Kuantitatif untuk Pengembangan Disiplin Akuntansi. Jurusan Akuntansi. Fakultas Ekonomi dan Bisnis Universitas Brawijaya. Malang.

Tsabita, R. (2014). Mengungkap Ketidakadilan Dalam Praktik Pembiayaan Mudharabah : Studi Fenomenologi. Thesis tidak dipublikasikan. Program Magister Ilmu Akuntansi. Pascasarjana Fakultas Ekonomi dan Bisnis Universitas Brawijaya Malang.

Undang-Undang Dasar 1945 Pasal 33

Undang-Undang Nomor 25 Tahun 1992 Tentang Perkoperasian

Widyaningrum, T. (2017). Rekonstruksi Pendidikan Perpajakan Di Wearnes Education Center: Suatu Kajian Kritis Tentang Etika Profesi. Thesis tidak dipublikasikan. Program Magister Akuntansi. Pascasarjana Fakultas Ekonomi dan Bisnis Universitas Brawijaya Malang.

Wildaniyati, A. (2006). Penerapan Prinsip Good Corporate Governance Pada Unit Usaha Syariah. Thesis tidak dipublikasikan. Magister Akuntansi. Fakultas Ekonomi dan Bisnis 
Universitas Brawijaya Malang.

Dewan Pengurus Nasional Fordebi dan Adesy. (2016). Ekonomi Dan Bisnis Islam, Seri Konsep dan Aplikasi Ekonomi Dan Bisnis Islam. PT. RajaGrafindo Persada. Cetakan ke-1. Jakarta. Indonesia

Zulfa, M. (2012). Persoalan Riba dalam Aktifitas Pelepas Modal: Tinjauan Humanisme dan Moralitas Agama. Itjihad, Jurnal Wacana Hukum Islam dan Kemanusiaan. Vol. 12, No. 1 Hal 63-64. 